University of Nebraska - Lincoln

DigitalCommons@University of Nebraska - Lincoln

Temperature but not ocean acidification affects energy metabolism and enzyme activities in the blue mussel, Mytilus edulis

Omera B. Matoo

Gisela Lannig

Christian Bock

Inna M. Sokolova

Follow this and additional works at: https://digitalcommons.unl.edu/bioscifacpub

Part of the Biology Commons

This Article is brought to you for free and open access by the Papers in the Biological Sciences at DigitalCommons@University of Nebraska - Lincoln. It has been accepted for inclusion in Faculty Publications in the Biological Sciences by an authorized administrator of DigitalCommons@University of Nebraska - Lincoln. 


\section{Temperature but not ocean acidification affects energy metabolism and enzyme activities in the blue mussel, Mytilus edulis}

\section{Omera B. Matoo ${ }^{1,2}$ (D) | Gisela Lannig ${ }^{3}$ | Christian Bock ${ }^{3}$ | Inna M. Sokolova ${ }^{2,4}$}

\author{
${ }^{1}$ School of Biological Sciences, University of \\ Nebraska-Lincoln, Lincoln, NE, USA \\ ${ }^{2}$ Department of Biological Sciences, \\ University of North Carolina at Charlotte, \\ Charlotte, NC, USA \\ ${ }^{3}$ Helmholtz Centre for Polar and Marine \\ Research, Alfred Wegener Institute, \\ Bremerhaven, Germany \\ ${ }^{4}$ Department of Marine Biology, Institute \\ of Biological Sciences, Universität Rostock, \\ Rostock, Germany

\section{Correspondence} \\ Omera B. Matoo, School of Biological \\ Sciences, University of Nebraska-Lincoln, \\ Lincoln, NE 68588, USA. \\ Email: omatoo2@unl.edu \\ Funding information \\ National Science Foundation, Grant/Award \\ Number: IOS-1557870
}

\begin{abstract}
1. In mosaic marine habitats, such as intertidal zones, ocean acidification (OA) is exacerbated by high variability of $\mathrm{pH}$, temperature, and biological $\mathrm{CO}_{2}$ production. The nonlinear interactions among these drivers can be context-specific and their effect on organisms in these habitats remains largely unknown, warranting further investigation.
\end{abstract}

2. We were particularly interested in Mytilus edulis (the blue mussel) from intertidal zones of the Gulf of Maine (GOM), USA, for this study. GOM is a hot spot of global climate change (average sea surface temperature (SST) increasing by $>0.2^{\circ} \mathrm{C} /$ year) with $>60 \%$ decline in mussel population over the past 40 years.

3. Here, we utilize bioenergetic underpinnings to identify limits of stress tolerance in M. edulis from GOM exposed to warming and OA. We have measured wholeorganism oxygen consumption rates and metabolic biomarkers in mussels exposed to control and elevated temperatures ( $10 \mathrm{vs.} 15^{\circ} \mathrm{C}$, respectively) and current and moderately elevated $P_{\mathrm{CO} 2}$ levels ( 400 vs. $800 \mu$ atm, respectively).

4. Our study demonstrates that adult M. edulis from GOM are metabolically resilient to the moderate OA scenario but responsive to warming as seen in changes in metabolic rate, energy reserves (total lipids), metabolite profiles (glucose and osmolyte dimethyl amine), and enzyme activities (carbonic anhydrase and calcium ATPase).

5. Our results are in agreement with recent literature that OA scenarios for the next 100-300 years do not affect this species, possibly as a consequence of maintaining its in vivo acid-base balance.

KEYWORDS

energy metabolism, global warming, Mytilus, NMR-based metabolomics, ocean acidification 


\section{1 | INTRODUCTION}

Continued increase in atmospheric $\mathrm{CO}_{2}$ and its subsequent uptake by oceans profoundly affects marine ecosystems (IPCC, 2014). Changes experienced by organisms include an increase in the global sea surface temperature (SST) and oceans' partial pressure of $\mathrm{CO}_{2}$ $\left(P_{\mathrm{CO} 2}\right)$, which leads to ocean acidification (OA) (Doney et al., 2012). Climate change models predict an average increase of $1.8-4.0^{\circ} \mathrm{C}$ (with some estimates as high as $6.4^{\circ} \mathrm{C}$ ) and a decline by $0.3-0.4 \mathrm{pH}$ units by the year 2100 , depending on the $\mathrm{CO}_{2}$ emission scenario (IPCC, 2014). Warming and OA can negatively impact marine organisms (Kroeker et al., 2013, 2014). However, in mosaic habitats such as intertidal and coastal zones, the outcome of multiple drivers, including warming and $\mathrm{OA}$, is complicated by context-specific and nonlinear interactions among the drivers (Gunderson et al., 2016 and references therein) so that the net effect could be additive, antagonistic, or synergistic (Todgham \& Stillman, 2013). The species' response to interactive effects of warming and $O A$ in such environments remains largely unknown and warrants further investigation (Gunderson et al., 2016).

Temperature is a key variable that affects physiology, survival, and distribution of ectotherms (Kroeker et al., 2013, 2014). Deviation of temperature from the optimum results in disturbance of energy balance and decrease in aerobic scope of organisms (Pörtner, 2012; Sokolova, 2013; Sokolova et al., 2012). OA negatively affects survival, metabolism, calcification, growth, reproduction, and immune responses across a range of marine taxa (Kroeker et al., 2013). Elevated $P_{\mathrm{CO} 2}$ shifts the acid-base balance of organisms (Melzner et al., 2009) and most calcifiers have limited capacity to counteract OA-induced extracellular acidosis (Pörtner, 2008). This in turn can increase the energy costs to maintain cellular and organismal homeostasis in animals (Ivanina et al., 2020; Pörtner, 2008; Sokolova et al., 2012; Stapp et al., 2018; Stumpp et al., 2012).

Responses of marine molluscs to $\mathrm{OA}$ are highly variable (Sokolova et al., 2015 and references therein). Inter- and intrapopulation variability in OA sensitivity has been shown depending on habitat, scales of environmental variability, and other concomitant stressors (Parker et al., 2011; Stapp et al., 2017; Vargas et al., 2017; Waldbusser et al., 2015). In mosaic environments, local adaptation, as well as temporally and spatially varying selection, can select for metabolically plastic, stress-tolerant genotypes that can maintain optimal phenotypes (including energetic sustainability) in a broad range of environmental conditions. Importantly, bioenergetic responses can predict tolerance limits under environmentally realistic scenarios of stress exposure (Sokolova et al., 2012) providing a common denominator to integrate responses to multiple stressors. Quantifying the independent and interactive effects of multiple stressors to identify metabolic tipping points is essential to determine the impact of global climate change on marine organisms and ecosystems (Boyd \& Brown, 2015).

This study aims to determine the interactive effects of elevated temperature and $P_{\mathrm{CO} 2}$ on energy metabolism and biomineralizationrelated enzymes in an ecologically and economically important bivalve mollusk, the blue mussel Mytilus edulis Linnaeus 1758. It is a critical foundation species in coastal ecosystems (Seed, 1969) that increasingly faces risk of local extinction along the USA east coast (Jones et al., 2009; Sorte et al., 2017). We were particularly interested in mussel populations from intertidal zones of Gulf of Maine (GOM), USA, for this study. GOM is a hot spot of global climate change with $>60 \%$ (range $29 \%-100 \%$ ) decline in mussel population over the past 40 years (Sorte et al., 2017). Within GOM, the previous decade has witnessed an average warming of $>0.2^{\circ} \mathrm{C}$ /year (Sorte et al., 2017). Satellite observations of SST within the GOM show that the region was warming at a faster rate than $99 \%$ of the global ocean (Pershing et al. 2015), with the highest average annual values exceeding over 150 years of observations held in NOAA's Merged Land-Ocean Surface Temperature Analysis database (Salisbury \& Jönsson, 2018). Combined with poor buffering capacity of the seawater in the coastal GOM regions (Ekstrom et al., 2015), temperature alone produces an annual change of 0.013 in $\mathrm{pH}$ and 1.06 in $\Omega_{\mathrm{AR}}$ (Salisbury \& Jönsson, 2018). Modeling data indicate that these rapid changes in the GOM together with physical processes in the area (e.g., strong tides, wind-driven mixing, coastal currents, and adjacent equilibrium with Northwestern Atlantic) alter ocean carbonate parameters but also mitigate the decrease, or even raise $\mathrm{pH}$ (Salisbury \& Jönsson, 2018). Mussels inhabiting GOM are thus exposed to one of the fastest rates of warming in the world, in addition to ocean acidification.

The metabolic plasticity of M. edulis to the combined effects of elevated $P_{\mathrm{CO} 2}$ and temperature from GOM is not yet fully understood. Here, we utilize the bioenergetic underpinnings of stress physiology to identify limits and mechanisms of stress tolerance in M. edulis. We tested the hypothesis that elevated temperature will exacerbate the effects of ocean acidification, resulting in elevated basal energy metabolism, which may decrease the amount of energy reserves and reduce enzyme activities involved in energy-demanding process of shell formation. To this end, we measured whole-organism oxygen consumption rates and metabolic biomarkers in mussels exposed to control and moderately elevated temperatures $\left(10 \mathrm{vs} .15^{\circ} \mathrm{C}\right)$ and $P_{\mathrm{CO} 2}$ ( 400 vs. $800 \mu \mathrm{atm}$ ) to mimic a realistic scenario of ocean warming and acidification. Standard metabolic rate (SMR) represents the basal energy cost for maintenance and is widely used to assess stress response (Pettersen et al., 2018). To account for possible tissue-specific variation in responses, we conducted a comprehensive analyses of the bioenergetic health index by measuring energy-related biomarkers (cellular and tissue energy reserves), metabolic profiles, and specific enzyme activities (acid-base regulating enzyme and energy-demanding ion transport enzymes) in different tissues depending on their physiological role. In mollusks, including M. edulis, carbonic anhydrase (CA) is the major acid-base regulating enzyme (Li et al., 2016; Ramesh et al., 2020; Wang et al., 2017). It plays a key role in gas exchange, acid-base regulation, calcification, and ion transport. Given the central role of CA, its activity is likely to play an important part in physiological mechanisms of acclimatization and tolerance of marine calcifiers, including M. edulis, to $\mathrm{CO}_{2}$-induced shifts in ocean chemistry as well as to other stressors such as temperature, salinity, or pollution. However, the fundamental 
TABLE 1 Summary of water chemistry parameters during experimental exposure

\begin{tabular}{|c|c|c|c|c|}
\hline Parameters & \multicolumn{4}{|c|}{ Assay temperature } \\
\hline Salinity, PSU & $30.04 \pm 0.07$ & $30.50 \pm 0.03$ & $30.15 \pm 0.04$ & $30.14 \pm 0.05$ \\
\hline Temperature, ${ }^{\circ} \mathrm{C}$ & $9.51 \pm 0.06$ & $9.76 \pm 0.02$ & $14.95 \pm 0.01$ & $14.99 \pm 0.01$ \\
\hline$P_{\mathrm{CO} 2}, \mu a t m$ & $585.39 \pm 39$ & $1,026.97 \pm 15.07$ & $536.14 \pm 4.35$ & $1,069.41 \pm 13.90$ \\
\hline $\mathrm{HCO}_{3}{ }^{-},(\mu \mathrm{mol} / \mathrm{kg} \mathrm{SW})$ & $2,735.82 \pm 2.91$ & $2,863.82 \pm 3.49$ & $2,628.49 \pm 2.73$ & $2,823.22 \pm 2.89$ \\
\hline $\mathrm{CO}_{3}{ }^{2-}(\mu \mathrm{mol} / \mathrm{kg} \mathrm{SW})$ & $155.50 \pm 1.23$ & $100.37 \pm 1.49$ & $202.67 \pm 1.18$ & $118.56 \pm 1.24$ \\
\hline $\mathrm{CO}_{2}(\mu \mathrm{mol} / \mathrm{kg} \mathrm{SW})$ & $26.85 \pm 0.26$ & $46.42 \pm 0.67$ & $20.66 \pm 0.16$ & $41.03 \pm 0.53$ \\
\hline$\Omega_{\text {calcite }}$ & $3.80 \pm 0.02$ & $2.44 \pm 0.03$ & $4.97 \pm 0.02$ & $2.91 \pm 0.03$ \\
\hline
\end{tabular}

Note: Salinity, temperature, $\mathrm{pH}_{\mathrm{NBS}}$, and dissolved inorganic carbon (DIC) were measured in water samples collected during the exposure. Average $\mathrm{DIC}$ was $2,953.75 \pm 111.28 \mu \mathrm{mol} / \mathrm{kg}$ SW. Other parameters are calculated using co2SYS. Data are represented as means \pm SEM. The same batch of seawater was used throughout the course of the experiment with an average total alkalinity (TA) of 3,098.40 mmol/ $\mathrm{kg} \mathrm{SW}$. N $=5$ for DIC and $N=36-77$ for other parameters.

information about the tissue distribution and thermal sensitivity of CA kinetics in M. edulis is not known. We, therefore, analyzed the tissue distribution and temperature sensitivity (determined by apparent activation energy and Arrhenius breakpoint temperature) of CA activity here in a separate set of experiment. This will provide the muchneeded data about the nuanced role of CA in regulation of acid-base balance and biomineralization in M. edulis.

\section{2 | MATERIALS AND METHODS}

\section{1 | Chemicals}

Unless otherwise indicated, all chemicals and enzymes were purchased from Sigma-Aldrich, Roche, or Fisher Scientific and were of analytical grade or higher.

\section{2 | Animal collection, maintenance and experimental design}

Blue mussels $M$. edulis were collected from Biddeford Pool, Gulf of Maine $\left(43^{\circ} 26^{\prime} 50.6 \mathrm{~N}, 70^{\circ} 21^{\prime} 19.0 \mathrm{~W}\right)$ in early summer 2011 and shipped on ice by an overnight delivery to the University of North Carolina at Charlotte. Mussels were kept in tanks with recirculating artificial seawater (ASW) (Instant Ocean ${ }^{\circledR}$, Kent Marine) at $9.6 \pm 0.3^{\circ} \mathrm{C}$ and $30 \pm 1$ salinity (practical salinity units, PSU), aerated with ambient air for 10 days. Mussels were then randomly assigned to four treatment groups, and each group was exposed for 4 weeks to one of the four possible combinations of two levels of $P_{\mathrm{CO} 2}$ and two temperatures. The two selected $P_{\mathrm{CO} 2}$ levels were representative of the present-day conditions ( $400 \mu$ atm $P_{\mathrm{CO} 2}$; normocapnia) and atmospheric $P_{\mathrm{CO} 2}$ concentrations predicted by a moderate scenario of the Intergovernmental Panel for Climate Change (IPCC) for the year 2100 ( 800 $\mu$ atm $P_{\text {CO2 }}$; hypercapnia) (IPCC, 2014). The temperatures were chosen to represent the average water temperature of mussels at the time of collection $\left(10^{\circ} \mathrm{C}\right)$, and $\mathrm{a}+5^{\circ} \mathrm{C}$ increase predicted for the year 2100 by an IPCC scenario 'business-as-usual' $\left(15^{\circ} \mathrm{C}\right)$. Both experimental temperatures are within the environmentally relevant range for the studied mussel population in the GOM. For the bivalves exposed to elevated temperature, water temperature in the tanks was slowly raised from $10^{\circ} \mathrm{C}$ by $1^{\circ} \mathrm{C}$ per day until $15^{\circ} \mathrm{C}$ was achieved and the experimental exposures began.

Two replicate tanks were set for each experimental treatment. Water in normocapnic treatments was bubbled with ambient air whereas for hypercapnic treatments ambient air was mixed with $100 \% \mathrm{CO}_{2}$ (Roberts Oxygen, Charlotte, NC,USA) using precision mass flow controllers (Cole-Parmer, Vernon Hills, IL, USA). The air- $\mathrm{CO}_{2}$ mixture flow rate was set up to maintain the respective systems at a steady-state $\mathrm{pH}$. Animals were fed ad libitum on alternative days with $2 \mathrm{ml}$ per tank of commercial algal mixture containing Isochrysis spp., Pavlova spp., Thalassoisira weissflogii, and Tetraselmis spp. with 5-20 $\mu \mathrm{m}$ cells (Shellfish Diet 1800, Reed Mariculture, Campbell, CA, USA). Mortality was checked daily and animals that gaped and did not respond to a mechanical stimulus were recorded as dead and immediately removed. Artificial Sea Water (ASW) for all exposures were prepared using the same batch of Instant Ocean ${ }^{\circledR}$ (Kent Marine, Acworth, GA, USA) salt to avoid potential variations in water chemistry. Carbonate chemistry of seawater was determined periodically during experimental exposures as described elsewhere (Beniash et al., 2010). Seawater temperature and chemistry data are shown in Table 1.

\section{3 | Standard metabolic rate}

Standard metabolic rate was measured as resting oxygen consumption $\left(\mathrm{MO}_{2}\right)$ of mussels at their respective acclimation temperature 
and $P_{\mathrm{CO} 2}$ using microfiber optic oxygen probes (Tx-Type, PreSens $\mathrm{GmbH}$, Germany, www.presens.de) as described in Matoo et al., 2013. Two-point calibration was performed at each temperature and $P_{\mathrm{CO} 2}$ concentration. Mussels were placed into flowthrough respiration chambers and allowed to recover overnight. To avoid interference with postprandial metabolism and feces excretion, animals were fasted for $24 \mathrm{hr}$ prior to the start of $\mathrm{MO}_{2}$ recordings. Water flow (20-25 $\mathrm{ml} / \mathrm{min}$ ) was adjusted so that animals consumed less than $25 \%$ of $\mathrm{O}_{2}$ at all times to avoid potential inhibitory effects of low oxygen levels on respiration rate. 10 biological replicates for each temperature and $P_{\mathrm{CO} 2}$ group were randomized across chambers and respirometry runs. After each individual run for $\sim 12 \mathrm{hr}$, the animals were dissected to determine wet tissue mass. Dry tissue mass was calculated from the wet tissue mass assuming an average water content of $80 \%$.

SMR was calculated as follows:

$$
\mathrm{SMR}=\frac{\Delta \mathrm{P}_{\mathrm{O} 2} \times \beta_{\mathrm{O} 2} \times V_{\mathrm{fl}}}{M^{0.8}}
$$

SMR-oxygen consumption ( $\mu$ mol $\mathrm{O}_{2} \mathrm{~g}^{-1}$ dry mass $\mathrm{h}^{-1}$ ) normalized to $1 \mathrm{~g}$ dry mass, $\Delta \mathrm{P}_{\mathrm{O} 2}$-difference in partial pressure between in- and outflowing water ( $\mathrm{kPa}), \beta_{\mathrm{O} 2}$-oxygen capacity of water $\left(\mu \mathrm{mol} \mathrm{O}_{2} \mathrm{~L}^{-1} \mathrm{kPa}^{-1}\right.$ ), $\mathrm{Vfl}-$ flow rate $(\mathrm{L} / \mathrm{h}), \mathrm{M}$-dry tissue mass $(\mathrm{g})$ and 0.8 -allometric coefficient (Bougrier et al., 1995).

After acclimation, a subset of mussels was dissected, tissues shock-frozen, and stored in liquid nitrogen for analyses of energy reserves and enzyme activities. Due to limited amount of tissues, we divided samples for different assays depending on the physiological function of a given tissue. The energy reserves (lipids, glycogen, and/or adenylates) were measured in hepatopancreas and adductor muscle that serve as reserve storage sites in bivalves (Cappello et al., 2018). Metabolite profiles were explored by untargeted metabolomics in two metabolically active aerobic tissues, the gills, and the muscle. The effects of warming and OA on biomineralization were assessed by the activities of three key enzymes involved in shell formation (carbonic anhydrase (CA), plasma membrane calcium $\left(\mathrm{Ca}^{2+}\right)$ ATPase, and proton $\left(\mathrm{H}^{+}\right)$ATPase) in the mantle tissue as the main organ involved in shell formation.

\section{4 | Energy reserves}

Lipid content was determined using the chloroform extraction method as described in Ivanina et al., 2013. Concentration of lipids was expressed as $\mathrm{g} / \mathrm{g}$ wet tissue mass. Concentrations of glycogen and adenylates ( $\mu \mathrm{mol} \mathrm{g} \mathrm{g}^{-1}$ wet tissue mass) were measured using standard NADH- or NADPH-linked spectrophotometric tests described in Ivanina et al., 2013. Adenylate energy charge (AEC) was calculated as follows:

$$
\mathrm{AEC}=\frac{[\mathrm{ATP}]+0.5 \times[\mathrm{ADP}]}{[\mathrm{ATP}]+[\mathrm{ADP}]+[\mathrm{AMP}]}
$$

\section{5 | Metabolic profiling based on ${ }^{1} \mathrm{H}-\mathrm{NMR}$ spectroscopy}

Samples of the muscle and gill tissues were extracted as described elsewhere for untargeted metabolic profiling using NMR spectroscopy (Dickinson et al., 2012; Lannig et al., 2010). Frozen tissues were homogenized under the liquid nitrogen and extracted with ice-cold perchloric acid (PCA, 0.6 M). Samples were homogenized by ultrasonic treatment $\left(0^{\circ} \mathrm{C}, 360 \mathrm{~W}\right)$ and centrifuged $\left(0^{\circ} \mathrm{C}, 2 \mathrm{~min}, 16,000 \mathrm{~g}\right)$ to remove precipitated protein. Supernatants were neutralized to $\mathrm{pH} 7.0-7.5$ using potassium hydroxide and centrifuged to remove precipitated potassium perchloride. Extracts were freeze-dried and shipped on dry ice to the Alfred Wegener Institute (Bremerhaven, Germany) for NMRbased metabolic profiling. Untargeted metabolic profiling using ${ }^{1} \mathrm{H}$-NMR spectroscopy was performed using a method modified from Schmidt et al. 2017. Samples were dissolved in $\mathrm{D}_{2} \mathrm{O}$ containing $1 \%$ trimethylsilylpropanoic acid (TSP) as internal standard to achieve a constant extract/TSP ratio. Typically, a sample volume of $70 \mu \mathrm{l}$ was transferred to a HRMAS rotor and placed into a triple tuned high-resolution magic angle spinning (HRMAS) probe of a wide-bore $400 \mathrm{MHz}$ NMR spectrometer (9.4T Bruker Avance III HD, Bruker Biospin). NMR spectra were collected at a temperature of $4^{\circ} \mathrm{C}$ and a spinning rate of $3,000 \mathrm{~Hz}$. A set of 1D$1 \mathrm{H}-\mathrm{NMR}$ spectra were collected from every sample including a classical one-pulse with water saturation protocol (Bruker's zgpr), a Carr-Purcell-Meiboom-Gill (cpmg) sequence used for quantification, a NOESY protocol and a J-resolved (JRES) protocol for signal identification with parameters as described in (Schmidt et al. 2017). For each sample, 32 scans with a spectral width of $5,000 \mathrm{~Hz}$ were collected in $64 \mathrm{~K}$ data points. The measuring protocol lasted $\sim 28 \mathrm{~min}$ per sample. ${ }^{1} \mathrm{H}$-NMR spectra from the cpmg protocol were used to analyze the metabolic profiles. Spectra were processed with an exponential multiplication $(\mathrm{lb}=0.3)$ and automatically phase- and baseline-corrected using Topsin 3.2 (Bruker Biospin). A total of 24 metabolites was identified from processed tissue spectra and quantified using Chenomx NMR suite 8.1 (Chenomx Inc.). Metabolic profiles were analyzed and tested for statistically significant changes between groups using MetaboAnalyst 4.0 (Chong et al. 2019).

\subsection{Enzyme activities}

Activities of biomineralization-related enzymes were measured in the mantle edge tissue (a 2-3 mm wide edge along the ventral shell margin functionally specialized for biomineralization) of M. edulis exposed to different temperature and $P_{\mathrm{CO} 2}$ conditions. Mantle edge expresses biomineralization-related genes and is involved in shell deposition in mussels and other bivalves (Bjärnmark et al., 2016; Gazeau et al., 2014). Protein concentrations were determined using Bradford assay (Bradford, 1976) and used to standardize enzyme activities. 


\subsection{1 | Carbonic anhydrase (CA)}

For assessment of carbonic anhydrase (carbonate hydrolyase, EC 4.2.1.1) activity, mantle edge tissue was homogenized as described in Ivanina et al., 2013. CA activity was determined as acetazolamide (AZM)-sensitive esterase activity with $1.5 \mathrm{mM}$ of $\mathrm{p}$-nitrophenyl acetate as a substrate (Gambhir et al., 2007) using a temperature-controlled spectrophotometer (VARIAN Cary 50 Bio UV-Vis spectrophotometer). In a separate set of experiments, CA activity was measured at different temperatures in an environmentally relevant range $\left(5-35^{\circ} \mathrm{C}\right)$ in the gill, mantle, adductor muscle, and hepatopancreas of the control mussels to characterize the tissue-dependent capacity and temperature sensitivity (determined by apparent activation energy $\left(E_{a}\right)$ and Arrhenius breakpoint temperature (ABT)) of CA activity. $E_{a}$ was determined from an Arrhenius plot of $\ln \left(V_{\text {max }}\right)$ against $1 / T\left(K^{-1}\right)$, and $A B T$ was determined as a point when the slope of Arrhenius plot significantly changed using an algorithm for multi-segment linear regression (Oosterbaan, 2011).

\subsubsection{Calcium $\left(\mathrm{Ca}^{2+}\right)$ and proton $\left(\mathrm{H}^{+}\right)$ATPases}

Mantle edge tissue was homogenized and activities of $\mathrm{Ca}^{2+}$-ATPase (EC 3.6.3.8) and $\mathrm{H}^{+}$-ATPase (EC 3.6.3.6) were assayed as described in Ivanina et al., 2020. Inorganic phosphate $\left(P_{\mathrm{j}}\right)$ was measured using malachite green assay kit (ab65622, Abcam) and ATPase activities were expressed as $\mu \mathrm{mol}$ of $P_{\mathrm{i}} \mu \mathrm{g}$ protein $^{-1} \mathrm{hr}^{-1}$.

\section{7 | Statistical analyses}

Effects of temperature, $P_{\mathrm{CO} 2}$, and their interaction were assessed for all studied traits using generalized linear model (GLM) ANOVA. All factors were treated as fixed and post hoc tests (Fisher's least significant difference) were used to test differences between group means. The number of biological replicates was 5-10 for all experimental groups. Regression analysis for ABT and Arrhenius plots for CA were done using GraphPad Prism ver. 4.03 (GraphPad Software, Inc.) and SegReg software (Oosterbaan, 2011). For statistical analysis of the metabolic profiles, we used MetaboAnalyst 4.0 (Chong et al., 2019) as described elsewhere (Rebelein et al., 2018). A partial least square discriminant analysis (PLS-DA) was used for separation of groups. Important metabolites were ranked based on Variable Importance in Projection (VIP) score of the PLS-DA. Significantly different metabolites were identified using the Significance Analysis of Microarray (SAM) approach for high-dimensional data analysis in small sample sizes with a Delta of 0.5 within MetaboAnalyst. SAM addresses the false discovery rate (FDR) on manifold repeated tests on the data. Significant scores are assigned by comparing the changes of each metabolite with the standard deviation of repeated measurements of a distribution estimated by random permutations (Tusher et al. 2001). A SAM plot compares the observed relative differences by the expected relative differences from the permutation results. Metabolites that showed a particular pattern were identified using PatternHunter analysis within MetaboAnalyst (Pavlidis \& Noble, 2001).

Unless otherwise indicated, data are shown as means \pm standard errors of means (SEM). Differences were considered significant if probability of type I error was $<0.05$.

\section{3 | RESULTS}

ANOVA analysis showed a significant effect of the acclimation temperature of the SMR, total lipid content of hepatopancreas, and activities of $\mathrm{CA}$ and $\mathrm{Ca}^{2+}$-ATPase in the mantle tissues of M. edulis (Table 2). No significant effects of the acclimation temperature were found for glycogen levels in the hepatopancreas, ATP, ADP, AMP or AEC in the adductor muscle, or $\mathrm{H}^{+}$-ATPase activity in the mantle. Acclimation $P_{\mathrm{CO} 2}$ or temperature $\times P_{\mathrm{CO} 2}$ interactions had no significant effect on any of the studied bioenergetics- or biomineralization-related traits in M. edulis (Table 2).

\subsection{Effects of warming and OA on SMR}

Warming significantly elevated SMR $(p<0.001)$ of M. edulis (Figure 1a; Table 2). After 4 weeks acclimation, SMR was $\sim 2-3$ times higher in mussels maintained at $15^{\circ} \mathrm{C}$ compared to $10^{\circ} \mathrm{C}$. This effect was observed under normocapnia $(p=0.002)$ and hypercapnia $(p=0.009)$. OA did not significantly affect SMR in mussels $(p=0.070)$, although a trend of elevated SMR was observed in OA-exposed mussels.

\section{2 | Tissue energy status under warming and OA}

Warming significantly increased the total lipid content in hepatopancreas under normocapnia $(p=0.05)$ and hypercapnia $(p=0.001)$ (Figure 1b; Table 2). OA did not significantly change the lipid content in hepatopancreas, regardless of the temperature $(p=0.608$ and 0.288 at 10 and $15^{\circ} \mathrm{C}$, respectively).

No significant changes were observed for glycogen (Figure 1c) and adenylates (Figure 2) content under warming, OA, or OA combined with warming (OWA) in the muscle of M. edulis (Table 2).

\section{3 | Tissue-specific shifts in metabolite profile under warming and $\mathrm{OA}$}

Untargeted NMR-based metabolic profiling in gill and muscle of M. edulis revealed minor shifts in metabolite concentrations under warming, OA and OWA. In gills, PLS-DA revealed a significant separation of $10^{\circ} \mathrm{C}$ - and $15^{\circ} \mathrm{C}$-acclimated groups (Figure 3a), indicating a temperature-induced change in branchial metabolism. According to their VIP scores, DMA and glucose were the main metabolites leading to these differences (Figure 3b). The levels of DMA decreased and glucose levels increased under warming, regardless of $P_{\mathrm{CO} 2}$ (Figure 4a). These two metabolites were also identified as significantly different 
TABLE 2 ANOVA results of the effects of exposure temperature, $P_{\mathrm{CO} 2}$, and their interaction on energy-related indices and enzyme activities in Mytilus edulis

\begin{tabular}{|c|c|c|c|}
\hline Parameter & Temperature & $P_{\mathrm{CO} 2}$ & Temperature $\times P_{\mathrm{CO} 2}$ \\
\hline $\begin{array}{l}\text { Standard Metabolic } \\
\text { Rate (SMR) }\end{array}$ & $F_{1,28}=24.97, p<0.0001$ & $\begin{array}{c}F_{1,28}=3.55 \\
p=0.07\end{array}$ & $F_{1,28}=0.00, p=0.98$ \\
\hline Total Lipids & $F_{1,20}=16.63, p=0.0006$ & $\begin{array}{c}F_{1,20}=0.16 \\
p=0.69\end{array}$ & $F_{1,20}=1.30, p=0.26$ \\
\hline Glycogen & $F_{1,35}=0.17, p=0.68$ & $\begin{array}{c}F_{1,35}=0.85 \\
p=0.36\end{array}$ & $F_{1,35}=0.56, p=0.45$ \\
\hline ATP & $F_{1,20}=0.61, p=0.44$ & $\begin{array}{c}F_{1,20}=3.16 \\
p=0.09\end{array}$ & $F_{1,20}=0.03, p=0.86$ \\
\hline ADP & $F_{1,20}=3.14, p=0.09$ & $\begin{array}{c}F_{1,20}=0.70 \\
p=0.41\end{array}$ & $F_{1,20}=0.38, p=0.54$ \\
\hline AMP & $F_{1,20}=1.08, p=0.31$ & $\begin{array}{c}F_{1,20}=0.14 \\
p=0.71\end{array}$ & $F_{1,20}=0.95, p=0.34$ \\
\hline AEC & $F_{1,20}=2.39, p=0.13$ & $\begin{array}{c}F_{1,20}=0.97 \\
p=0.33\end{array}$ & $F_{1,20}=0.16, p=0.69$ \\
\hline Carbonic Anhydrase & $F_{1,20}=6.70, p=0.01$ & $\begin{array}{c}F_{1,20}=1.17 \\
p=0.29\end{array}$ & $F_{1,20}=0.04, p=0.83$ \\
\hline Calcium ATPase & $F_{1,19}=9.86, p=0.005$ & $\begin{array}{c}F_{1,19}=0.01 \\
p=0.90\end{array}$ & $F_{1,20}=0.18, p=0.67$ \\
\hline Proton ATPase & $F_{1,7}=0.03, p=0.86$ & $\begin{array}{c}F_{1,17}=1.13 \\
p=0.30\end{array}$ & $F_{1,17}=3.25, p=0.08$ \\
\hline
\end{tabular}

Note: $F$-values are given with degrees of freedom for the factor and error in the subscript. Significant values $(p<0.05)$ are highlighted in bold.

Abbreviation: AEC, adenylate energy change.
$395 \mu \mathrm{atm}$

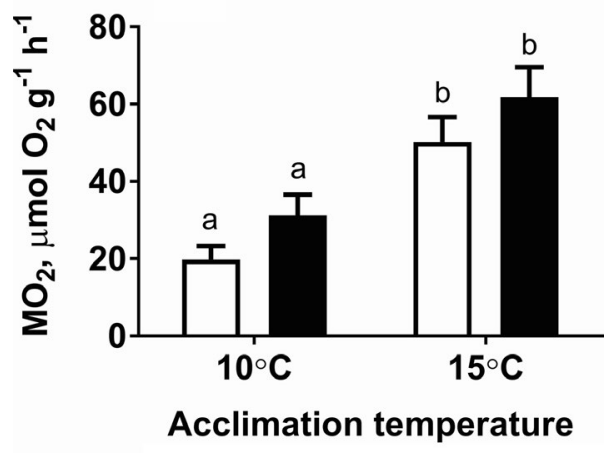

FIGURE 1 Oxygen consumption rates of Mytilus edulis exposed to different temperatures and $P_{\mathrm{CO} 2}$. The traits were measured in mussels groups at their respective acclimation temperatures (10 vs. $\left.15^{\circ} \mathrm{C}\right)$ and $P_{\mathrm{CO} 2}(\sim 400$ vs. $800 \mu$ atm). Within each graph, different letters indicate means are significantly different $(p<0.05)$. Vertical bars represent SEM. $N=8-10$

between the temperature groups by SAM analysis (Figure 4b). Unlike gills, metabolite profiles of adductor muscle were not affected by temperature or $P_{\mathrm{CO} 2}$ (see PLS-DA in Figure S3).

\subsection{Effects of warming and OA on enzyme activity}

Carbonic anhydrase activity in the mantle of $M$. edulis showed an elevated trend under warming ( $p=0.001$ for temperature effects) but did not under OA ( $p=0.30$ ) (Figure 5a; Table 2). When data for normocapnia and hypercapnia were pooled, a significant increase in CA activity at $15^{\circ} \mathrm{C}$ compared to $10^{\circ} \mathrm{C}(p=0.018)$ was detected (Figure S1). Tissue-specific CA activity over a broad temperature range $\left(5-35^{\circ} \mathrm{C}\right)$ showed a significant effect of two-factor (temperature $x$ tissue) interactions ( $p<0.0001)$. CA activity was significantly higher in the hepatopancreas compared to other tissues (Figure $5 b$ ). Irrespective of the tissue, CA activity monotonously increased with increasing temperatures with similar $E_{a}\left(32.5-43.8 \mathrm{~kJ} / \mathrm{mol} \mathrm{K}^{-1}\right)$ and no $A B T$ in the studied tissues (data not shown).

$\mathrm{Ca}^{2+}$-ATPase activity from the mantle edge of $M$. edulis was significantly affected by warming ( $p=0.005)$ but not OA ( $p=0.905)$ (Figure 6a; Table 2). Warming led to a significant decrease in $\mathrm{Ca}^{2+}$ ATPase activity under hypercapnia $(p=0.023)$ but not under normocapnia $(p=0.060)$.

$\mathrm{H}^{+}$-ATPase activity from the mantle edge of $M$. edulis was not significantly affected by warming $(p=0.862)$ or OA $(p=0.303)$ (Figure $6 \mathrm{~b}$, Table 2). At $10^{\circ} \mathrm{C}$, hypercapnia led to a decrease in the $\mathrm{H}^{+}$-ATPase activity, but this decrease was nonsignificant $(p=0.06)$.

\section{4 | DISCUSSION}

Our study demonstrates that adult M. edulis from GOM are metabolically resilient to moderate $\mathrm{OA}\left(P_{\mathrm{CO} 2} \sim 800 \mu \mathrm{atm}\right)$ but responsive to warming as seen in changes in whole-body metabolic rate, energy reserves, metabolite profiles, and enzyme activities. The combination of ocean warming and acidification (OWA) did not elicit 
$395 \mu \mathrm{atm}$

$800 \mu \mathrm{atm}$

(a)

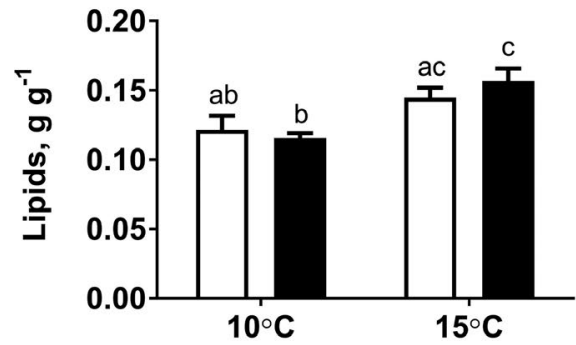

(c)

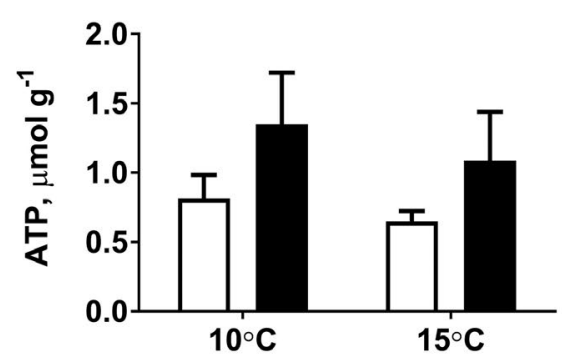

(e)

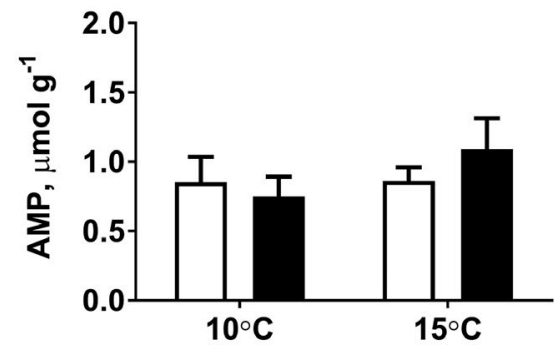

Acclimation temperature (b)

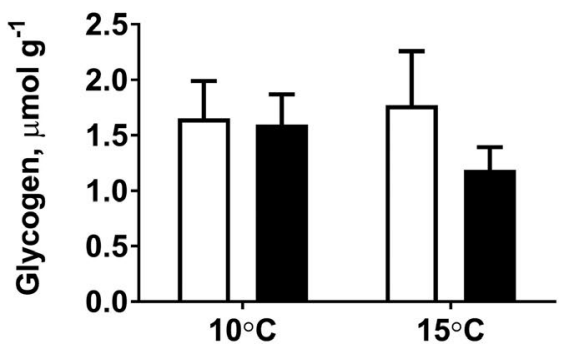

(d)

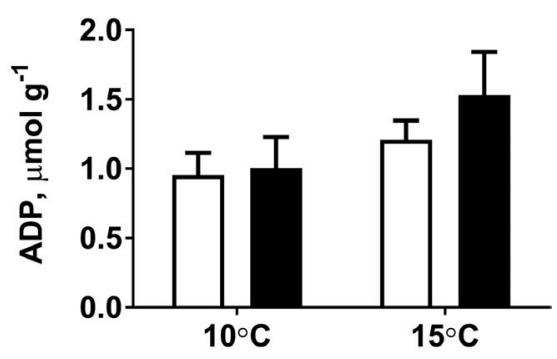

(f)

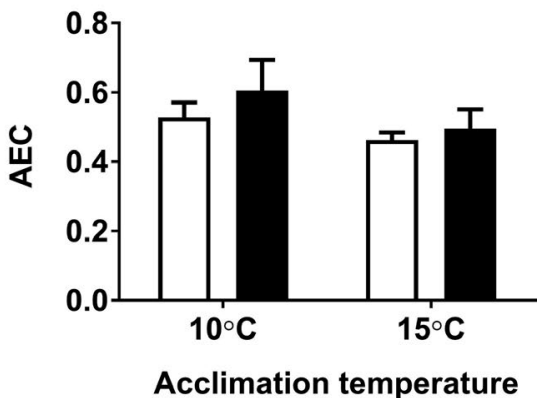

FIGURE 2 Tissue energy reserves and concentrations of adenylates of Mytilus edulis exposed to different temperatures and $P_{\mathrm{CO} 2}$. (a) Total lipids, (b) glycogen, (c) ATP, (d) ADP, (e) AMP, and (f) adenylate energy charge (AEC). The total lipid content was measured in hepatopancreas, all other traits-in the adductor muscle. Within each graph, different letters indicate means are significantly different $(p<0.05)$. If the columns have no letters, the respective means are not significantly different between different $P_{\mathrm{CO} 2}$ and temperature $(p>0.05)$. Vertical bars represent SEM. $N=6-10$ detrimental metabolic changes in mussels beyond the effect of warming. This indicates that under these conditions, temperature is the dominant factor in determining species' physiology. Intertidal pools, in general, are very dynamic environments with variations of temperature, $\mathrm{pH}$ and $\mathrm{CO}_{2}$ levels, where seawater $\mathrm{pH}$ can fluctuate from 8.1 to 6.9-6.5 (and $P_{\mathrm{CO} 2}$ can change from 400 $\mu$ atm to more than $10,000-40,000 \mu \mathrm{atm}$ ) due to biological $\mathrm{CO}_{2}$ production and/or freshwater inflow, and temperature fluctuations can exceed $15-20^{\circ} \mathrm{C}$ during diurnal, tidal and seasonal cycles with local geographical factors moderating these variables (Burnett, 1997; Chapman et al., 2011; Ringwood \& Keppler, 2002). The physiological responses of mussels in our study might be related to their ecology in GOM. There is a high temporal variability in temperature (annual SST range $15.5^{\circ} \mathrm{C}$ ) in temperate rocky intertidal pools of GOM throughout the year (Salisbury \& Jönsson, 2018). Thus, M. edulis in this region are predominantly exposed to large variation in temperature which might explain their plasticity to thermal stress. Earlier studies in M. edulis populations from thermal clines of GOM showed high phenotypic plasticity in physiology despite lack of population genetic structure and local adaptation (Lesser, 2016; Lesser et al., 2010) consistent with the findings of metabolic plasticity to warming found in our study.

\subsection{Effect of warming and OA on bioenergetics}

We observed a $~ 2-3$-fold increase in SMR of mussels exposed to $5^{\circ} \mathrm{C}$ warming under normocapnia or hypercapnia, indicating a strong temperature effect on metabolism with $Q_{10} \sim 4-6$. A $5^{\circ} \mathrm{C}$ increase is well within the range of temperature fluctuations experienced by mussels in GOM (Salisbury \& Jönsson, 2018). Blue mussels are eurythermal and well adapted for $5-20^{\circ} \mathrm{C}$ range, with an upper thermal tolerance limit of $\sim 29^{\circ} \mathrm{C}$ for adults (Gosling, 1992). Therefore, temperatures in our study are within the ecological relevant and even optimal range for this species. On the other hand, Pejus temperatures represent thermal transitions where organisms mount compensatory mechanisms that divert away from performance parameters with direct fitness correlates (Zittier et al., 2015). Previous studies have shown that the circulatory system of $M$. edulis reached its temperature-induced capacity limit above $25^{\circ} \mathrm{C}$, indicating the onset of the Pejus range at this temperature (Zittier et al., 2015). The elevated SMR at $15^{\circ} \mathrm{C}$ seen in the present study, therefore, reflects the rate-enhancing effects of temperature on physiological and biochemical reactions such as activities of metabolic enzymes, ion channels, mitochondria, and other important bioenergetic processes (Hochachka, 1973). 
FIGURE 3 PLS-DA analysis of metabolite profiles in the gill tissues of Mytilus edulis exposed to different temperatures and $P_{\mathrm{CO} 2}$. (a) 3D-loading plot of first three components separating the metabolic profiles from Warming and OWA groups (blue crosses and teal diamonds) from control (red triangles). The OA group (green plus) did not separated from control. (b) Important metabolites identified by PLS-DA. The colored squares on the right show group-specific relative changes in metabolite concentration. Groups: Ctr-control (acclimated at $10^{\circ} \mathrm{C}$ and normocapnia), OA-ocean acidification (acclimated at $10^{\circ} \mathrm{C}$ and hypercapnia), W-warming (acclimated at $15^{\circ} \mathrm{C}$ and normocapnia), OWA-ocean warming and acidification (acclimated at $15^{\circ} \mathrm{C}$ and hypercapnia)

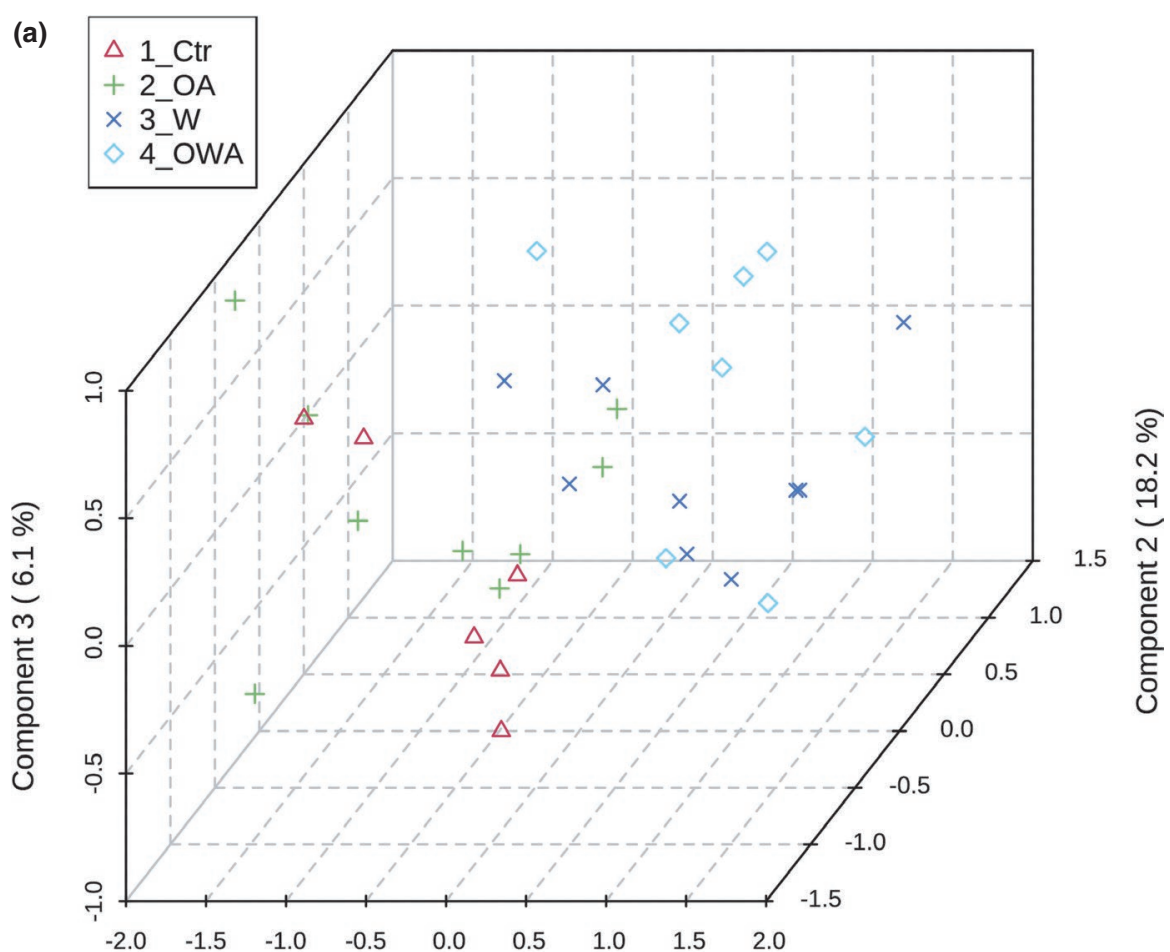

Component 1 ( $32.7 \%)$

(b)

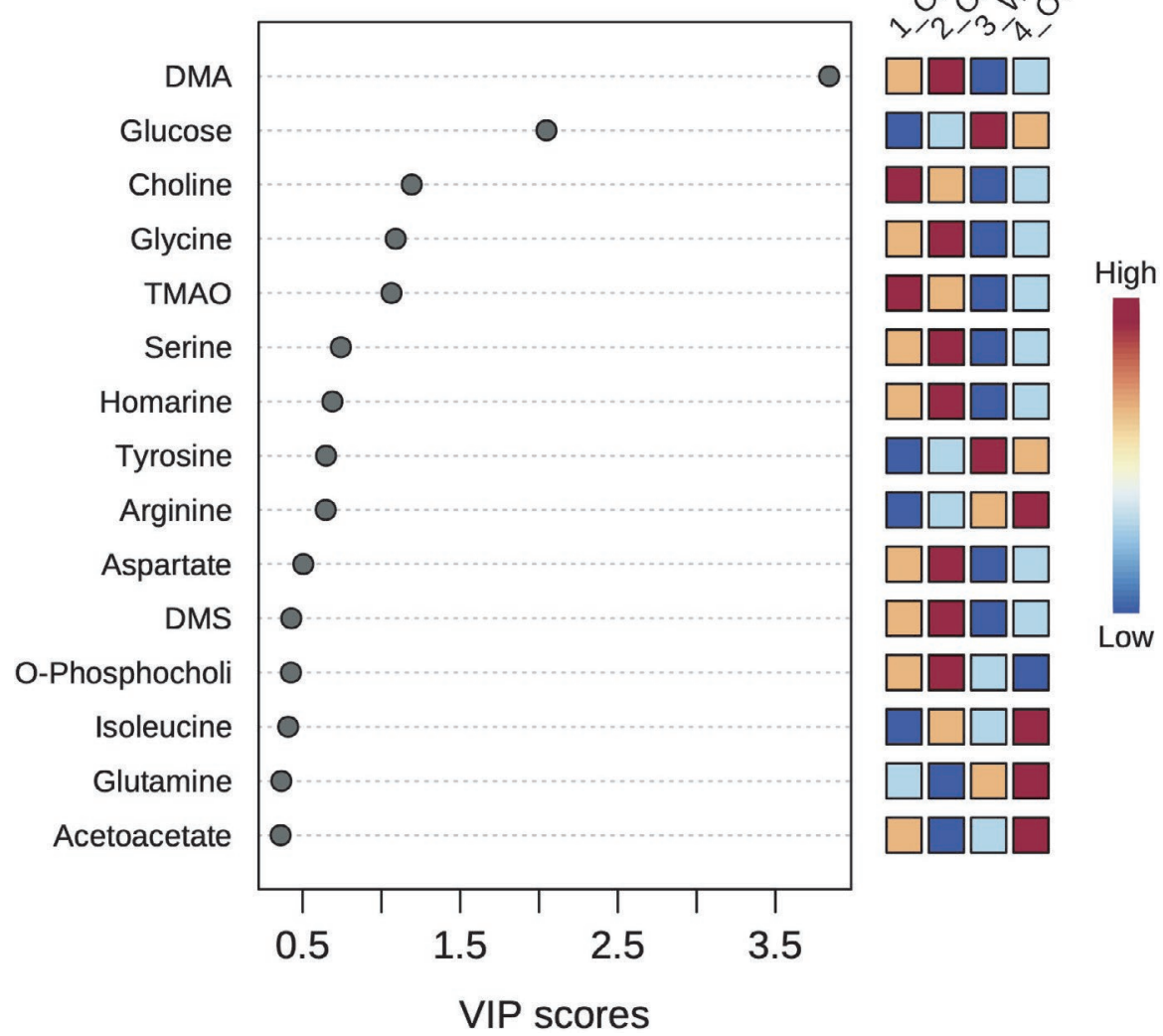

Recent meta-analysis also indicates that temperature threshold for long-term survival of M. edulis is $20^{\circ} \mathrm{C}$ (Lupo et al., 2021). Therefore, $20^{\circ} \mathrm{C}$ appears to be close to the metabolic optimum of M. edulis, so rate-enhancing effects of temperature dominate over the potentially negative impacts on metabolism as long as warming occurs below the $20^{\circ} \mathrm{C}$ threshold, as in our study.

Unlike temperature effect, modest OA had no effect on SMR regardless of the temperature. Metabolic response to $\mathrm{OA}$ in $\mathrm{M}$. edulis 
(a)

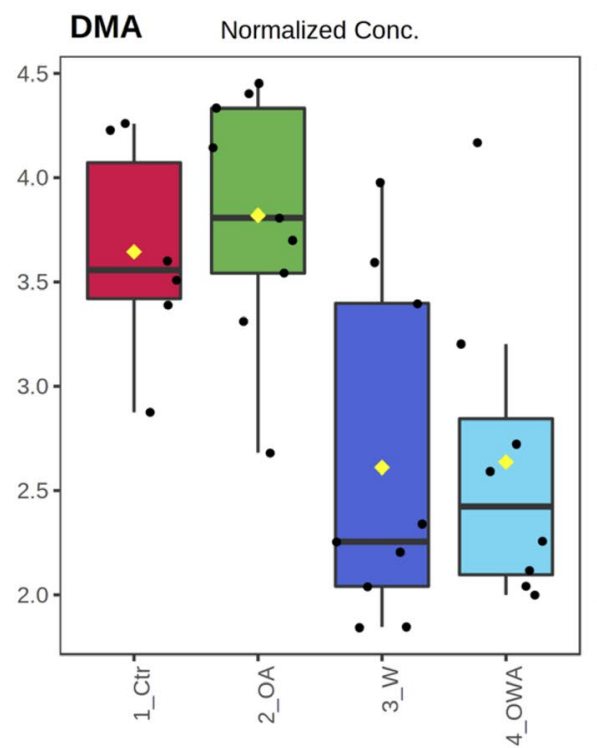

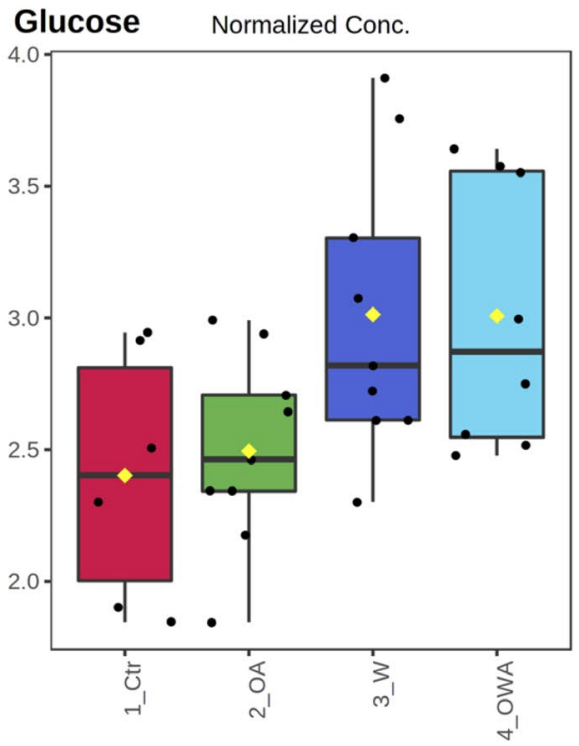

FIGURE 4 (a) Tissue levels (given in normalized concentrations) of DMA and glucose in gill tissues of Mytilus edulis exposed to different temperatures and $P_{\mathrm{CO} 2}$. Groups: $\mathrm{Ctr}-$ control (acclimated at $10^{\circ} \mathrm{C}$ and normocapnia), OA-ocean acidification (acclimated at $10^{\circ} \mathrm{C}$ and hypercapnia), W-warming (acclimated at $15^{\circ} \mathrm{C}$ and normocapnia), OWA-ocean warming and acidification (acclimated at $15^{\circ} \mathrm{C}$ and hypercapnia). (b) Significance Analysis of Microarray (SAM) plot of gill tissue. Scatter plot showing observed relative differences on the axis of ordinates against the expected relative differences estimated by data permutation on the abscise using a delta of 0.5 (dotted lines). The green dots are highlighting significant differences and correspond to DMA and glucose (b)

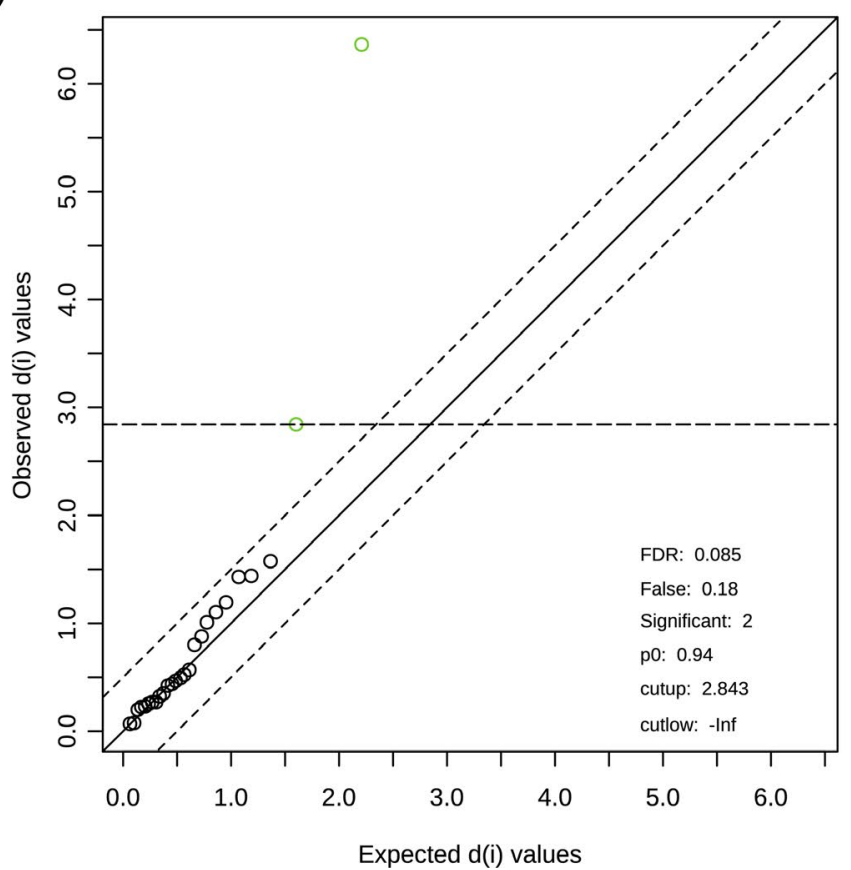

can vary and depend on magnitude of $P_{\mathrm{CO} 2}$, food availability, and population (Fitzer et al., 2014; Hüning et al., 2013; Lesser, 2016; Thomsen et al., 2013; Thomsen \& Melzner, 2010; Zittier et al., 2015). Fitzer et al. (2014) showed that for M. edulis at 1,000 $\mu$ atm and beyond, biomineralization continued but with compensated protein metabolism and shell growth indicating that $1,000 \mu$ atm could be an OA metabolic tipping point for M. edulis. In our study, $\mathrm{P}_{\mathrm{CO} 2}$ levels were below this threshold and could explain the physiological tolerance of mussels seen here. Our hypothesis that $P_{\mathrm{CO} 2}$ could exacerbate the increase of SMR caused by elevated temperature was not supported in this study. The outcome of OWA on metabolic rate in bivalves is commonly additive; albeit in other cases, the effects of temperature or $P_{\mathrm{CO} 2}$ dominate (see Lefevre, 2016 and references therein). Furthermore, metabolic responses of bivalves to OWA are dependent on the degree of temperature or $P_{\mathrm{CO} 2}$ stress. For example, Lesser, 2016 showed that mussels from GOM showed metabolic depression as a protective response when exposed to combined stress of higher warming $\left(22^{\circ} \mathrm{C}\right)$ and modestly elevated $P_{\mathrm{CO} 2}(560 \mu \mathrm{atm})$.

Temperature (but not $\mathrm{OA}$ ) had a marked effect on lipid content in M. edulis. We observed an increase in lipids under warming in hepatopancreas, under both normocapnia and hypercapnia. In bivalves, lipids are primarily stored in hepatopancreas (Giese, 1966) and synthesis, storage, and use of lipids show pronounced seasonal cycles. Specifically, lipids are accumulated during summer (at high temperature and food availability) and used for metabolism and initiation of gametogenesis during winter (at low temperature and food 
availability) (Fokina et al., 2015). Laboratory studies indicate that lipid accumulation is a direct response to temperature in mussels (Fokina et al., 2015; Wu et al., 2021) and might reflect a metabolic adjustment for anticipated reproduction (which requires high energy investment as well as lipid deposition into developing gametes) in mussels.

Unlike lipids, the glycogen content did not change in response to warming in mussels from GOM. M. edulis from Baltic Sea also
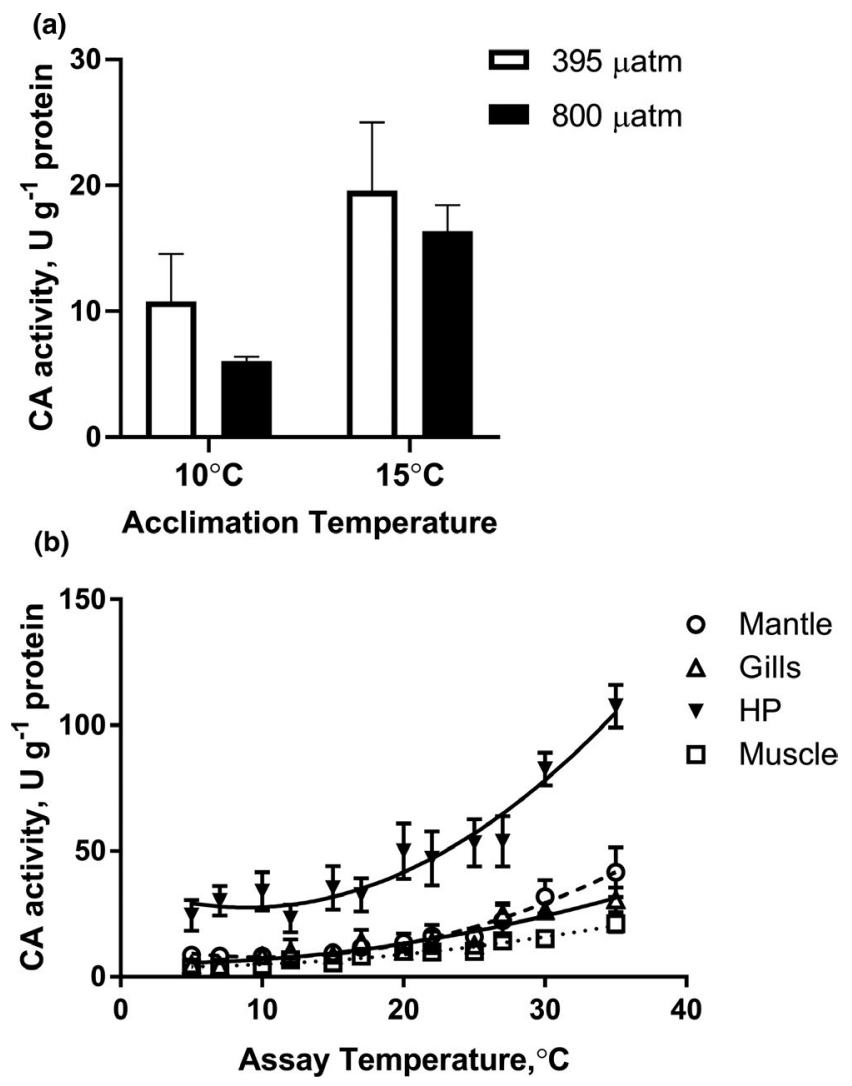

FIGURE 5 Carbonic anhydrase (CA) activity in tissues of Mytilus edulis. (a) CA activity in mantle edge exposed to different temperature and $P_{\mathrm{CO} 2}$. (b) Tissue-specific variation in specific activities of carbonic anhydrase with temperature. Vertical bars represent standard errors of means. HP-hepatopancreas. If the columns have no letters, the respective means are not significantly different $(p>0.05)$. Vertical bars represent SEM. $N=5-7$ showed no change in glycogen content during warming from 10 to $15^{\circ} \mathrm{C}$ and from 15 to $20^{\circ} \mathrm{C}$ (Wu et al., 2021). Modest hypercapnia likewise had no effect on the glycogen content of adductor muscle of mussels in our present study. Earlier studies show that impacts of temperature and OA on glycogen reserves of mussels are threshold dependent. Thus, mussels from GOM showed a marked decrease in the glycogen content of adductor muscle when exposed to higher temperature $\left(22^{\circ} \mathrm{C}\right)$ alone and combined with modest acidification (560 $\mu$ atm $P_{\mathrm{CO} 2}, \mathrm{pH}$ 7.9) (Lesser, 2016). The concentrations of adenylates and AEC in adductor muscle remained at steady-state levels in all exposures, indicating that cellular energy balance in mussels was maintained under all temperatures and OA scenarios. Overall, our findings indicate that temperature and OA used in our present study are not energetically stressful to GOM mussels (at least under ad libitum feeding conditions).

Warming alone or OWA altered the metabolite profile of M. edulis in a tissue-dependent manner. Warming from 10 to $15^{\circ} \mathrm{C}$ increased glucose and decreased dimethyl amine (DMA) in the gills, whereas adductor muscle metabolites were not affected. Increased glucose could reflect mobilization of energy reserves to meet increased tissue energy demand. Furthermore, warming could increase glucose levels via gluconeogenesis by channeling of amino acids like serine, alanine, and glycine into pyruvate and increased activity of the enzyme phosphoenolpyruvate carboxykinase (PEPCK) (Ellis et al., 2014; Le Moullac et al., 2007). In our study, we saw a trend for decreased glycine and serine in gills under warming and OWA, suggesting a potential for increased flux through gluconeogenesis that warrants further investigation. The decrease in DMA, a common organic osmolyte found in gills of bivalves (Zhang et al., 2011), might osmotically compensate for elevated glucose in M. edulis gills during warming.

In M. edulis, OA had no effect on the metabolite profile in gills or muscle tissue. Similarly, metabolite profiling studies with $P_{\mathrm{CO} 2} \leq \sim 1,000 \mu$ atm $(\mathrm{pH} \geq \sim 7.8)$ reported no OA-induced alteration in metabolite levels of bivalves (Dickinson et al., 2012; Ellis et al., 2014; Wei et al., 2015) whereas higher $P_{\mathrm{CO} 2}(\geq 1,500 \mu \mathrm{atm}, \mathrm{pH} \leq \sim 7.7)$ led to a shift in metabolite profiles with alterations in energy metabolism (Ellis et al., 2014; Lannig et al., 2010; Wei et al., 2015). These findings are consistent with the notion that modest $\mathrm{OA}$ is not a metabolic (a)

FIGURE 6 ATPases activity in mantle edge of Mytilus edulis exposed to different temperatures and $P_{\mathrm{CO} 2}$ levels. (a) Calcium $\left(\mathrm{Ca}^{2+}\right)$ ATPase and (b) proton $\left(\mathrm{H}^{+}\right)$ATPase. Within each graph, different letters indicate means are significantly different $(p<0.05)$. If the columns share a letter, the respective values are not significantly different $(p>0.05)$. Vertical bars represent SEM. $N=5-6$

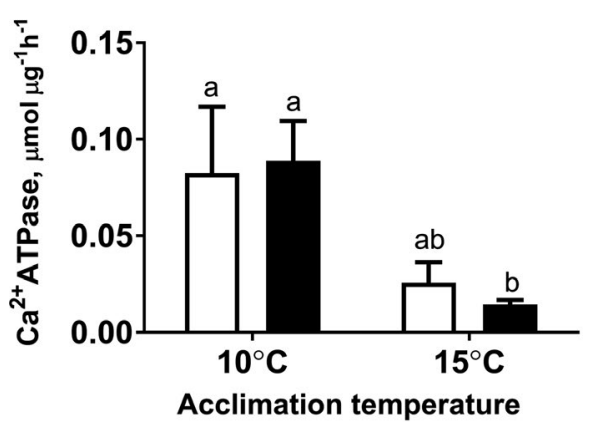

(b)

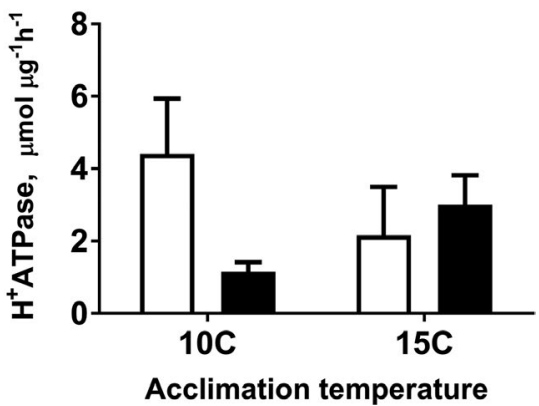


stressor for M. edulis, and the studied GOM population follows this general pattern.

\subsection{Effect of warming and OA on enzyme activity}

In mollusks, CA plays a key role in the maintenance of acid-base homeostasis of all tissues as well as biomineralization in the mantle (Li et al., 2016; Ramesh et al., 2020; Wang et al., 2017). In M. edulis, CA activity increased with acute warming $\left(5-35^{\circ} \mathrm{C}\right)$ in all tissues with similar $E_{a}$ values indicating a concerted whole-body response of this enzyme to warming. No Arrhenius breakpoint temperature $(A B T)$ was found for $C A$ activity from 5 to $35^{\circ} \mathrm{C}$ indicating high thermal tolerance of this enzyme. We found highest CA levels in hepatopancreas as compared to other tissues (gills, muscle and mantle) in M. edulis. This might reflect differences in overall metabolic activity (and therefore, different metabolic $\mathrm{CO}_{2}$ and proton loads) among the tissues that require different levels of CA to maintain acid-base balance. Acclimation to $15^{\circ} \mathrm{C}$ upregulated CA activity in a key biomineralizing tissue (the mantle edge) of M. edulis. Similarly, long-term (15 weeks) exposure to elevated temperature $\left(27^{\circ} \mathrm{C}\right)$ led to a notable increase in CA activity in bivalves Crassostrea virginica and Mercenaria mercenaria (Ivanina et al., 2013). This increase is likely linked with the overall increase in metabolic rates at elevated temperatures and can assist with shell deposition.

CA activity remained unchanged in response to OA in mantle edge of M. edulis. Previous studies showed variable CA responses to OA in bivalves including mussels (Ivanina et al., 2020). Similar to our findings, $C A$ activity in the mantle of $C$. virginica and $M$. mercenaria remained unchanged after exposure to elevated $P_{\mathrm{CO} 2}(800 \mu \mathrm{atm})$ for 2-15 weeks (Ivanina et al., 2013). In contrast, CA activity in mantle of M. edulis decreased after prolonged (6-months) exposure to elevated $P_{\mathrm{CO} 2}(750 \mu \mathrm{atm})$ exposure (Fitzer et al., 2014). In oysters, CA accumulated along mantle edge in response to $P_{\mathrm{CO} 2}$ exposure $(2,622 \mu \mathrm{atm}$, $\mathrm{pH} 7.50$ ), suggesting an active role of $\mathrm{CA}$ in ion-regulation and acidbase balance (Wang et al., 2017). However, the effect of OA on CA activity is threshold dependent. At $P_{\mathrm{CO} 2}<1,000 \mu$ atm mussels try to compensate for intracellular acid loads instead of decreasing their metabolism (Fitzer et al., 2014; Hüning et al., 2013; Thomsen \& Melzner, 2010). Taken together, these data suggest that M. edulis in the GOM can upregulate acid-base balance contributing to their metabolic plasticity toward warming, but moderate OA has no effect on this trait.

As a consequence of maintaining acid-base balance, OA may change concentrations of $\mathrm{H}^{+}, \mathrm{HCO}_{3}{ }^{-}, \mathrm{Ca}^{2+}, \mathrm{Mg}^{2+}$, and $\mathrm{Cl}^{-}$in calcifiers (Fitzer et al., 2014; Ramesh et al., 2017). Ion transport is an important contributor to energy budget of biomineralization because $\mathrm{Ca}^{2+}$ transport and removal of excess protons from the site of biomineralization are ATP-dependent (Ivanina et al., 2020). In GOM mussels, activity of $\mathrm{Ca}^{+}$-ATPase and $\mathrm{H}^{2+}$-ATPase-in the mantle remained stable under moderate warming and OA (except for a modest but significant decline in $\mathrm{Ca}^{2+}$-ATPase under OWA). This indicates that the mussels can maintain ion regulatory fluxes at least in the mantle edge despite variations in temperature and $P_{\mathrm{CO} 2}$ relevant to nearfuture climate change. Mussels from other environments acidified like Kiel Fjord $(\mathrm{pH}<7.5)$ also build and maintain their shells despite fluctuating $P_{\mathrm{CO} 2}$ and $\mathrm{pH}$, partially owing to enhanced ion transport (Thomsen et al., 2013, 2017). Furthermore, when mussel larvae were raised under $\mathrm{OA}$ between 500 and 1,500 $\mu$ atm $\mathrm{P}_{\mathrm{CO} 2}, \Delta \mathrm{H}^{+}$at the calcification site when compared to seawater remained constant, irrespective of $P_{\mathrm{CO} 2}$ (Thomsen et al., 2013). In C. virginica and M. mercenaria activities of $\mathrm{Ca}^{2+}$ ATPase and $\mathrm{H}^{+}$ATPase, as well as the cellular energy costs of $\mathrm{Ca}^{2+}$ and $\mathrm{H}^{+}$transport in the biomineralizing cells (mantle and hemocytes) were insensitive to ocean acidification ( $\mathrm{pH}$ 7.8) (Ivanina et al., 2020). This indicates that intertidal species (such as mussels, oysters, and clams) that are adapted to variable temperature and $\mathrm{pH}$ in their habitat are generally tolerant against moderate warming and $\mathrm{OA}$, predicted by the climate change models.

\section{5 | CONCLUSIONS}

In this study, we report that adult M. edulis from GOM are sensitive to warming but tolerant to moderate acidification scenario predicted by IPCC for the year 2100. This result also provides an insight in the natural history of GOM mussels given that in the last decade (2005-2014) GOM was characterized by an extreme warming trend (Salisbury \& Jönsson, 2018). Although this study is limited to adults and does not consider larval stage sensitivity of $M$. edulis, our results support earlier reports that acidification scenarios for the next 100-300 years do not affect this species (Telesca et al., 2019). Taken together, our study provides important data about extant levels of plasticity in physiology of mussels as well as insights into potential sensitivity of mussels to future global change.

\section{ACKNOWLEDGMENTS}

The authors thank Dr. Markus Frederich (University of New England) for assistance with mussel collection in Gulf of Maine. This work was supported by the US National Science Foundation (NSF) award IOS1557870 to I.M.S.

\section{CONFLICT OF INTEREST}

The authors declare no conflict of interest.

\section{AUTHOR CONTRIBUTIONS}

Omera B. Matoo: Conceptualization (lead); formal analysis (lead); investigation (lead); methodology (lead); writing - original draft (lead); writing - review and editing (lead). Gisela Lannig: Data curation (equal); formal analysis (equal); visualization (equal); writing - review and editing (supporting). Christian Bock: Data curation (equal); formal analysis (equal); visualization (supporting); writing - review and editing (supporting). Inna M. Sokolova: Conceptualization (equal); funding acquisition (lead); methodology (equal); project administration (lead); resources (lead); writing - review and editing (supporting). 


\section{DATA AVAILABILITY STATEMENT}

Supplemental files are available at FigShare. Phenotypic data is deposited in the Dryad Digital Repository (https://doi.org/10.5061/ dryad.ffbg79ctf).

\section{ORCID}

Omera B. Matoo iD https://orcid.org/0000-0002-2795-0706

\section{REFERENCES}

Beniash, E., Ivanina, A., Lieb, N., Kurochkin, I., \& Sokolova, I. (2010). Elevated level of carbon dioxide affects metabolism and shell formation in oysters Crassostrea virginica. Marine Ecology Progress Series, 419, 95-108. https://doi.org/10.3354/meps08841

Bjärnmark, N., Yarra, T., Churcher, A., Felix, R., Clark, M., \& Power, D. (2016). Transcriptomics provides insight into Mytilus galloprovincialis (Mollusca: Bivalvia) mantle function and its role in biomineralisation. Marine Genomics, 27, 37-45. https://doi.org/10.1016/j. margen.2016.03.004

Bougrier, S., Geairon, P., Deslous-Paoli, J. M., Bacher, C., \& Jonquieres, G. (1995). Allometric relationships and effects of temperature on clearance and oxygen consumption rates of Crassostrea gigas (Thunberg). Aquaculture, 134, 143-154. https://doi. org/10.1016/0044-8486(95)00036-2

Boyd, P., \& Brown, C. (2015). Modes of interactions between environmental drivers and marine biota. Frontiers in Marine Science, 2, 9. https://doi.org/10.3389/fmars.2015.00009

Bradford, M. (1976). A rapid and sensitive method for the quantitation of microgram quantities of protein utilizing the principle of proteindye binding. Analytical Biochemistry, 72(1-2), 248-254. https://doi. org/10.1016/0003-2697(76)90527-3

Burnett, L. E. (1997). The challenges of living in hypoxic and hypercapnic aquatic environments. American Zoologist, 37(6), 633-640. https:// doi.org/10.1093/icb/37.6.633

Cappello, T., Giannetto, A., Parrino, V., Maisano, M., Oliva, S., De Marco, G., Guerriero, G., Mauceri, A., \& Fasulo, S. (2018). Baseline levels of metabolites in different tissues of mussel Mytilus galloprovincialis (Bivalvia: Mytilidae). Comparative Biochemistry and Physiology Part D: Genomics and Proteomics, 26, 32-39. https://doi.org/10.1016/j. cbd.2018.03.005

Chapman, R. W., Mancia, A., Beal, M., Veloso, A., Rathburn, C., Blair, A., Holland, A. F., Warr, G. W., Didinato, G., Sokolova, I. M., Wirth, E. F., Duffy, E., \& Sanger, D. (2011). The transcriptomic responses of the eastern oyster, Crassostrea virginica, to environmental conditions. Molecular Ecology, 20(7), 1431-1449. https://doi. org/10.1111/j.1365-294X.2011.05018.x

Chong, J., Wishart, D. S., \& Xia, J. (2019). Using MetaboAnalyst 4.0 for comprehensive and integrative metabolomics data analysis. Current Protocols in Bioinformatics, 68(1), e86. https://doi.org/10.1002/ cpbi.86

Dickinson, G. H., Ivanina, A. V., Matoo, O. B., Pörtner, H. O., Lannig, G., Bock, C., Beniash, E., \& Sokolova, I. M. (2012). Interactive effects of salinity and elevated $\mathrm{CO}_{2}$ levels on juvenile eastern oysters, Crassostrea virginica. Journal of Experimental Biology, 215(1), 29-43. https://doi.org/10.1242/jeb.061481

Doney, S. C., Ruckelshaus, M., Emmett Duffy, J., Barry, J. P., Chan, F., English, C. A., Galindo, H. M., Grebmeier, J. M., Hollowed, A. B., Knowlton, N., Polovina, J., Rabalais, N. N., Sydeman, W. J., \& Talley, L. D. (2012). Climate change impacts on marine ecosystems. Annual Review of Marine Sciences, 4, 11-37. https://doi.org/10.1146/annur ev-marine-041911-111611

Ekstrom, J. A., Suatoni, L., Cooley, S. R., Pendleton, L. H., Waldbusser, G. G., Cinner, J. E., Ritter, J., Langdon, C., van Hooidonk, R., Gledhill, D., Wellman, K., Beck, M. W., Brander, L. M., Rittschof, D., Doherty, C.,
Edwards, P. E. T., \& Portela, R. (2015). Vulnerability and adaptation of US shellfisheries to ocean acidification. Nature Climate Change, 5(3), 207-214. https://doi.org/10.1038/nclimate2508

Ellis, R., Spicer, J., Byrne, J., Sommer, U., Viant, M., White, D., \& Widdicombe, S. (2014). ${ }^{1}$ H NMR metabolomics reveals contrasting response by male and female mussels exposed to reduced seawater $\mathrm{pH}$, increased temperature, and a pathogen. Environmental Science \& Technology, 48(12), 7044-7052. https://doi.org/10.1021/es501601w

Fitzer, S., Phoenix, V., Cusack, M., \& Kamenos, N. (2014). Ocean acidification impacts mussel control on biomineralisation. Scientific Reports, 4, 6218. https://doi.org/10.1038/srep06218

Fokina, N. N., Lysenko, L. A., Sukhovskaya, I. V., Vdovichenko, E. A., Borvinskaya, E. V., Kantserova, N. P., Krupnova, M. Y., Ruokolainen, T. R., Smirnov, L. P., Vysotskaya, R. U., Bakhmet, I. N., \& Nemova, N. N. (2015). Biochemical response of blue mussels Mytilus edulis L. from the white sea to rapid changes in ambient temperature. Journal of Evolutionary Biochemistry and Physiology, 51(5), 378-387. https:// doi.org/10.1134/S0022093015050038

Gambhir, K., Ornasir, J., Headings, V., \& Bonar, A. (2007). Decreased total carbonic anhydrase esterase activity and decreased levels of carbonic anhydrase 1 isozyme in erythrocytes of type II diabetic patients. Biochemical Genetics, 45(5-6), 431-439. https://doi. org/10.1007/s10528-007-9086-x

Gazeau, F., Alliouane, S., Bock, C., Bramanti, L., LÃ $\tilde{A}^{3}$ ez Correa, M., Gentile, M., Hirse, T., PÃ Trtner, H.-O., \& Ziveri, P. (2014). Impact of ocean acidification and warming on the Mediterranean mussel (Mytilus galloprovincialis). Frontiers in Marine Science, 1, 62. https:// doi.org/10.3389/fmars.2014.00062

Giese, A. (1966). Lipids in the economy of marine invertebrates. Physiological Reviews, 46(2), 244-298. https://doi.org/10.1152/physr ev.1966.46.2.244

Gosling, E. (1992). The mussel Mytilus: Ecology, physiology, genetics and culture. Elsevier, Amsterdam.

Gunderson, A., Armstrong, E., \& Stillman, J. (2016). Multiple stressors in a changing world: The need for an improved perspective on physiological responses to the dynamic marine environment. Annual Review of Marine Science, 8, 357-378. https://doi.org/10.1146/annurev-marin e-122414-033953

Hochachka, W. P. (1973). Basic strategies and mechanisms of enzyme adaptation to temperature. In W. Wieser (Ed.), Effects of temperature on ectothermic organisms (pp. 69-81). Springer-Verlag.

Hüning, A. K., Melzner, F., Thomsen, J., Gutowska, M. A., Krämer, L., Frickenhaus, S., Rosenstiel, P., Pörtner, H.-O., Philipp, E. E. R., \& Lucassen, M. (2013). Impacts of seawater acidification on mantle gene expression patterns of the Baltic Sea blue mussel: Implications for shell formation and energy metabolism. Marine Biology, 160(8), 1845-1861. https://doi.org/10.1007/s00227-012-1930-9

IPCC (2014). Climate change 2014: Synthesis report. In Core Writing Team, R. K. Pachauri, \& L. A. Meyer (Eds.), Contribution of working groups I, II and III to the fifth assessment report of the Intergovernmental Panel on Climate Change. (151). IPCC, Geneva, Switzerland. https:// www.ipcc.ch/report/ar5/syr/

Ivanina, A. V., Dickinson, G. H., Matoo, O. B., Bagwe, R., Dickinson, A., Beniash, E., \& Sokolova, I. M. (2013). Interactive effects of elevated temperature and $\mathrm{CO}_{2}$ levels on energy metabolism and biomineralization of marine bivalves Crassostrea virginica and Mercenaria mercenaria. Comparative Biochemistry and Physiology - A Molecular and Integrative Physiology, 166(1), 101-111. https://doi.org/10.1016/j. cbpa.2013.05.016

Ivanina, A., Jarrett, A., Bell, T., Rimkevicius, T., Beniash, E., \& Sokolova, I. (2020). Effects of seawater salinity and pH on cellular metabolism and enzyme activities in biomineralizing tissues of marine bivalves. Comparative Biochemistry and Physiology Part A: Molecular \& Integrative Physiology, 248, 110748. https://doi.org/10.1016/j. cbpa.2020.110748 
Jones, S., Mieszkowska, N., \& Wethey, D. (2009). Linking thermal tolerances and biogeography: Mytilus edulis (L.) at its southern limit on the east coast of the United States. The Biological Bulletin, 217(1), 73-85.

Kroeker, K., Gaylord, B., Hill, T., Hosfelt, J., Miller, S., \& Sanford, E. (2014). The role of temperature in determining species' vulnerability to ocean acidification: A case study using Mytilus galloprovincialis. PLoS One, 9(7), e100353. https://doi.org/10.1371/journal.pone.0100353

Kroeker, K. J., Kordas, R. L., Crim, R., Hendriks, I. E., Ramajo, L., Singh, G. S., Duarte, C. M., \& Gattuso, J.-P. (2013). Impacts of ocean acidification on marine organisms: Quantifying sensitivities and interaction with warming. Global Change Biology, 19(6), 1884-1896. https://doi. org/10.1111/gcb.12179

Lannig, G., Eilers, S., Pörtner, H., Sokolova, I., \& Bock, C. (2010). Impact of ocean acidification on energy metabolism of oyster, Crassostrea gigas-changes in metabolic pathways and thermal response. Marine Drugs, 8(8), 2318-2339. https://doi.org/10.3390/md8082318

Le Moullac, G., Bacca, H., Huvet, A., Moal, J., Pouvreau, S., \& Van Wormhoudt, A. (2007). Transcriptional regulation of pyruvate kinase and phosphoenolpyruvate carboxykinase in the adductor muscle of the oyster Crassostrea gigas during prolonged hypoxia. Journal of Experimental Zoology Part A: Ecological Genetics and Physiology, 307(7), 371-382. https://doi.org/10.1002/jez.390

Lefevre, S. (2016). Are global warming and ocean acidification conspiring against marine ectotherms? A meta-analysis of the respiratory effects of elevated temperature, high $\mathrm{CO}_{2}$ and their interaction. Conservation Physiology, 4, 1-31. https://doi.org/10.1093/conphys/ cow009

Lesser, M. (2016). Climate change stressors cause metabolic depression in the blue mussel, Mytilus edulis, from the Gulf of Maine. Limnology and Oceanography, 61(5), 1705-1717. https://doi.org/10.1002/ Ino.10326

Lesser, M., Bailey, M., Merselis, D., \& Morrison, J. (2010). Physiological response of the blue mussel Mytilus edulis to differences in food and temperature in the Gulf of Maine. Comparative Biochemistry and Physiology Part A: Molecular \& Integrative Physiology, 156(4), 541-551. https://doi.org/10.1016/j.cbpa.2010.04.012

Li, S., Liu, C., Huang, J., Liu, Y., Zhang, S., Zheng, G., Xie, L., \& Zhang, R. (2016). Transcriptome and biomineralization responses of the pearl oyster Pinctada fucata to elevated $\mathrm{CO}_{2}$ and temperature. Scientific Reports, 6, 18943. https://doi.org/10.1038/srep18943

Lupo, C., Bougeard, S., Le Bihan, V., Blin, J., Allain, G., Azéma, P., Benoit, F., Béchemin, C., Bernard, I., Blachier, P., Brieau, L., Danion, M., Garcia, A., Gervasoni, E., Glize, P., Lainé, A., Lapègue, S., Mablouké, C., Poirier, L., \& Le Bouquin, S. (2021). Mortality of marine mussels Mytilus edulis and M. galloprovincialis: Systematic literature review of risk factors and recommendations for future research. Reviews in Aquaculture, n/a(n/a). 13, 504-536. https://doi.org/10.1111/ raq.12484

Matoo, O., Ivanina, A. V., Ullstad, C., Beniash, E., \& Sokolova, M. I. (2013). Interactive effects of elevated temperature and $\mathrm{CO}_{2}$ levels on metabolism and oxidative stress in two common marine bivalves (Crassostrea virginica and Mercenaria mercenaria). Comparative Biochemistry and Physiology - A Molecular and Integrative Physiology, 164(4), 545-553. https://doi.org/10.1016/j.cbpa.2012.12.025

Melzner, F., Gutowska, M., Langenbuch, M., Dupont, S., Lucassen, M., Thorndyke, M., Bleich, M., \& Pörtner, H. O. (2009). Physiological basis for high $\mathrm{CO}_{2}$ tolerance in marine ectothermic animals: Preadaptation through lifestyle and ontogeny? Biogeosciences, 6(10) 2313-2331. https://doi.org/10.5194/bg-6-2313-2009

Oosterbaan, R. (2011). SegReg: Segmented linear regression with breakpoint and confidence intervals. Retrieved from http://www.waterlog. info/segreg.htm

Parker, L., Ross, P., \& O'Connor, W. (2011). Populations of the Sydney rock oyster, Saccostrea glomerata, vary in response to ocean acidification.
Marine Biology, 158(3), 689-697. https://doi.org/10.1007/s0022 7-010-1592-4

Pavlidis, P., \& Noble, W. S. (2001). Analysis of strain and regional variation in gene expression in mouse brain. Genome Biology, 2(10), research0042.1-research0042.15. https://doi.org/10.1186/gb2001-2-10-research0042

Pershing, A. J., Alexander, M. A., Hernandez, C. M., Kerr, L. A., Le Bris, A., Mills, K. E., Nye, J. A., Record, N. R., Scannell, H. A., Scott, J. D., Sherwood, G. D., \& Thomas, A. C. (2015). Slow adaptation in the face of rapid warming leads to collapse of the Gulf of Maine cod fishery. Science, 350(6262), 809-812. https://doi.org/10.1126/scien ce.aac9819

Pettersen, A., Marshall, D., \& White, C. (2018). Understanding variation in metabolic rate. Journal of Experimental Biology, 221(1), jeb166876. https://doi.org/10.1242/jeb.166876

Pörtner, H. (2008). Ecosystem effects of ocean acidification in times of ocean warming: A physiologist's view. Marine Ecology Progress Series, 373, 203-217. https://doi.org/10.3354/meps07768

Pörtner, H. (2012). Integrating climate-related stressor effects on marine organisms: Unifying principles linking molecule to ecosystem-leve changes. Marine Ecology Progress Series, 470, 273-290. https://doi. org/10.3354/meps10123

Ramesh, K., Hu, M. Y., Melzner, F., Bleich, M., \& Himmerkus, N. (2020). Intracellular $\mathrm{pH}$ regulation in mantle epithelial cells of the Pacific oyster, Crassostrea gigas. Journal of Comparative Physiology B, 190, 691700. https://doi.org/10.1007/s00360-020-01303-3

Ramesh, K., Hu, M., Thomsen, J., Bleich, M., \& Melzner, F. (2017). Mussel larvae modify calcifying fluid carbonate chemistry to promote calcification. Nature Communications, 8, 1709. https://doi.org/10.1038/ s41467-017-01806-8

Rebelein, A., Pörtner, H., \& Bock, C. (2018). Untargeted metabolic profiling reveals distinct patterns of thermal sensitivity in two related notothenioids. Comparative Biochemistry and Physiology Part A: Molecular \& Integrative Physiology, 217, 43-54. https://doi. org/10.1016/j.cbpa.2017.12.012

Ringwood, A. H., \& Keppler, C. J. (2002). Water quality variation and clam growth: Is pH really a non-issue in estuaries. Estuaries, 25(5), 901907. https://doi.org/10.1007/BF02691338

Salisbury, J., \& Jönsson, B. (2018). Rapid warming and salinity changes in the Gulf of Maine alter surface ocean carbonate parameters and hide ocean acidification. Biogeochemistry, 141(3), 401-418. https:// doi.org/10.1007/s10533-018-0505-3

Schmidt, M., Windisch, H., Ludwichowski, K., Seegert, S., Pörtner, H., Storch, D., \& Bock, C. (2017). Differences in neurochemical profiles of two gadid species under ocean warming and acidification. Frontiers in Zoology, 14(1), 1-13. https://doi.org/10.1186/s12983-017-0238-5

Seed, R. (1969). The ecology of Mytilus edulis L. (Lamellibranchiata) on exposed rocky shores. Oecologia, 3(3), 317-350.

Sokolova, I. (2013). Energy-limited tolerance to stress as a conceptual framework to integrate the effects of multiple stressors. Integrative and Comparative Biology, 53(4), 597-608. https://doi.org/10.1093/ icb/ict028

Sokolova, I., Frederich, M., Bagwe, R., Lannig, G., \& Sukhotin, A. (2012). Energy homeostasis as an integrative tool for assessing limits of environmental stress tolerance in aquatic invertebrates. Marine Environmental Research, 79, 1-15. https://doi.org/10.1016/j.maren vres.2012.04.003

Sokolova, I. M., Matoo, O. B., Dickinson, G., \& Beniash, E. (2015). Physiological effects of ocean acidification on animal calcifiers. In S. N. Whiteley, \& M. Solan (Eds.), Stressors in the marine environments (pp. 36-55). Oxford University Press.

Sorte, C. J. B., Davidson, V. E., Franklin, M. C., Benes, K. M., Doellman, M. M., Etter, R. J., Hannigan, R. E., Lubchenco, J., \& Menge, B. A. (2017). Long-term declines in an intertidal foundation species parallel shifts 
in community composition. Global Change Biology, 23(1), 341-352. https://doi.org/10.1111/gcb.13425

Stapp, L., Parker, L., O'Connor, W., Bock, C., Ross, P., Poertner, H., \& Lannig, G. (2018). Sensitivity to ocean acidification differs between populations of the Sydney rock oyster: Role of filtration and ionregulatory capacities. Marine Environmental Research, 135, 103-113. https://doi.org/10.1016/j.marenvres.2017.12.017

Stapp, L., Thomsen, J., Schade, H., Bock, C., Melzner, F., Pörtner, H., \& Lannig, G. (2017). Intra-population variability of ocean acidification impacts on the physiology of Baltic blue mussels (Mytilus edulis): Integrating tissue and organism response. Journal of Comparative Physiology B, 187(4), 529-543. https://doi.org/10.1007/s0036 0-016-1053-6

Stumpp, M., Trübenbach, K., Brennecke, D., Hu, M. Y., \& Melzner, F. (2012). Resource allocation and extracellular acid-base status in the sea urchin Strongylocentrotus droebachiensis in response to $\mathrm{CO}_{2}$ induced seawater acidification. Aquatic Toxicology, 110, 194-207. https://doi.org/10.1016/j.aquatox.2011.12.020

Telesca, L., Peck, L., Sanders, T., Thyrring, J., Sejr, M., \& Harper, E. (2019). Biomineralization plasticity and environmental heterogeneity predict geographical resilience patterns of foundation species to future change. Global Change Biology, 25(12), 4179-4193. https://doi. org/10.1111/gcb.14758

Thomsen, J., Casties, I., Pansch, C., Körtzinger, A., \& Melzner, F. (2013). Food availability outweighs ocean acidification effects in juvenile Mytilus edulis: Laboratory and field experiments. Global Change Biology, 19(4), 1017-1027. https://doi.org/10.1111/gcb.12109

Thomsen, J., \& Melzner, F. (2010). Moderate seawater acidification does not elicit long-term metabolic depression in the blue mussel Mytilus edulis. Marine Biology, 157(12), 2667-2676. https://doi.org/10.1007/ s00227-010-1527-0

Thomsen, J., Stapp, L. S., Haynert, K., Schade, H., Danelli, M., Lannig, G., Wegner, K. M., \& Melzner, F. (2017). Naturally acidified habitat selects for ocean acidification-tolerant mussels. Science Advances, 3(4), e1602411. https://doi.org/10.1126/sciadv.1602411

Todgham, A., \& Stillman, J. (2013). Physiological responses to shifts in multiple environmental stressors: Relevance in a changing world. Integrative and Comparative Biology, 53(4), 539-544. https://doi. org/10.1093/icb/ict086

Tusher, V. G., Tibshirani, R., \& Chu, G. (2001). Significance analysis of microarrays applied to the ionizing radiation response. Proceedings of the National Academy of Sciences of the United States of America, 98(9), 5116-5121. https://doi.org/10.1073/pnas.091062498

Vargas, C. A., Lagos, N. A., Lardies, M. A., Duarte, C., Manríquez, P. H., Aguilera, V. M., Broitman, B., Widdicombe, S., \& Dupont, S. (2017). Species-specific responses to ocean acidification should account for local adaptation and adaptive plasticity. Nature Ecology \& Evolution, 1(4), 84. https://doi.org/10.1038/s41559-017-0084
Waldbusser, G. G., Hales, B., Langdon, C. J., Haley, B. A., Schrader, P., Brunner, E. L., Gray, M. W., Miller, C. A., \& Gimenez, I. (2015). Saturation-state sensitivity of marine bivalve larvae to ocean acidification. Nature Climate Change, 5(3), 273-280. https://doi. org/10.1038/nclimate2479

Wang, X., Wang, M., Jia, Z., Song, X., Wang, L., \& Song, L. (2017). A shellformation related carbonic anhydrase in Crassostrea gigas modulates intracellular calcium against $\mathrm{CO}_{2}$ exposure: Implication for impacts of ocean acidification on mollusk calcification. Aquatic Toxicology, 189, 216-228. https://doi.org/10.1016/j.aquatox.2017.06.009

Wei, L., Wang, Q., Ning, X., Mu, C., Wang, C., Cao, R., Wu, H., Cong, M., Li, F., Ji, C., \& Zhao, J. (2015). Combined metabolome and proteome analysis of the mantle tissue from Pacific oyster Crassostrea gigas exposed to elevated $\mathrm{pCO}_{2}$. Comparative Biochemistry and Physiology Part D: Genomics and Proteomics, 13, 16-23. https://doi. org/10.1016/j.cbd.2014.12.001

Wu, F., Sokolov, E., Dellwig, O., \& Sokolova, I. (2021). Season-dependent effects of $\mathrm{ZnO}$ nanoparticles and elevated temperature on bioenergetics of the blue mussel Mytilus edulis. Chemosphere, 263, 127780. https://doi.org/10.1016/j.chemosphere.2020.127780

Zhang, L., Liu, X., You, L., Zhou, D. I., Wu, H., Li, L., Zhao, J., Feng, J., \& Yu, J. (2011). Metabolic responses in gills of Manila clam Ruditapes philippinarum exposed to copper using NMR-based metabolomics. Marine Environmental Research, 72(1), 33-39. https://doi.org/10.1016/j. marenvres.2011.04.002

Zittier, Z., Bock, C., Lannig, G., \& Pörtner, H. O. (2015). Impact of ocean acidification on thermal tolerance and acid-base regulation of Mytilus edulis (L.) from the North Sea. Journal of Experimental Marine Biology and Ecology, 473, 16-25. https://doi.org/10.1016/j. jembe.2015.08.001

\section{SUPPORTING INFORMATION}

Additional supporting information may be found online in the Supporting Information section.

How to cite this article: Matoo OB, Lannig G, Bock C, Sokolova IM. Temperature but not ocean acidification affects energy metabolism and enzyme activities in the blue mussel, Mytilus edulis. Ecol Evol. 2021;11:3366-3379. https://doi.org/10.1002/ ece3.7289 